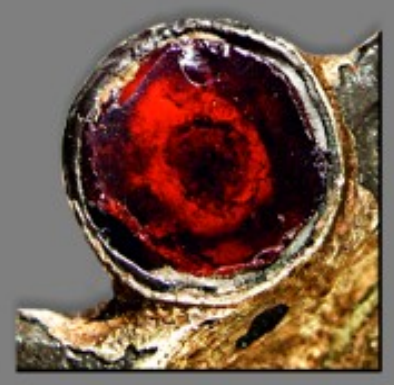

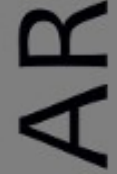

$\sim$

ш
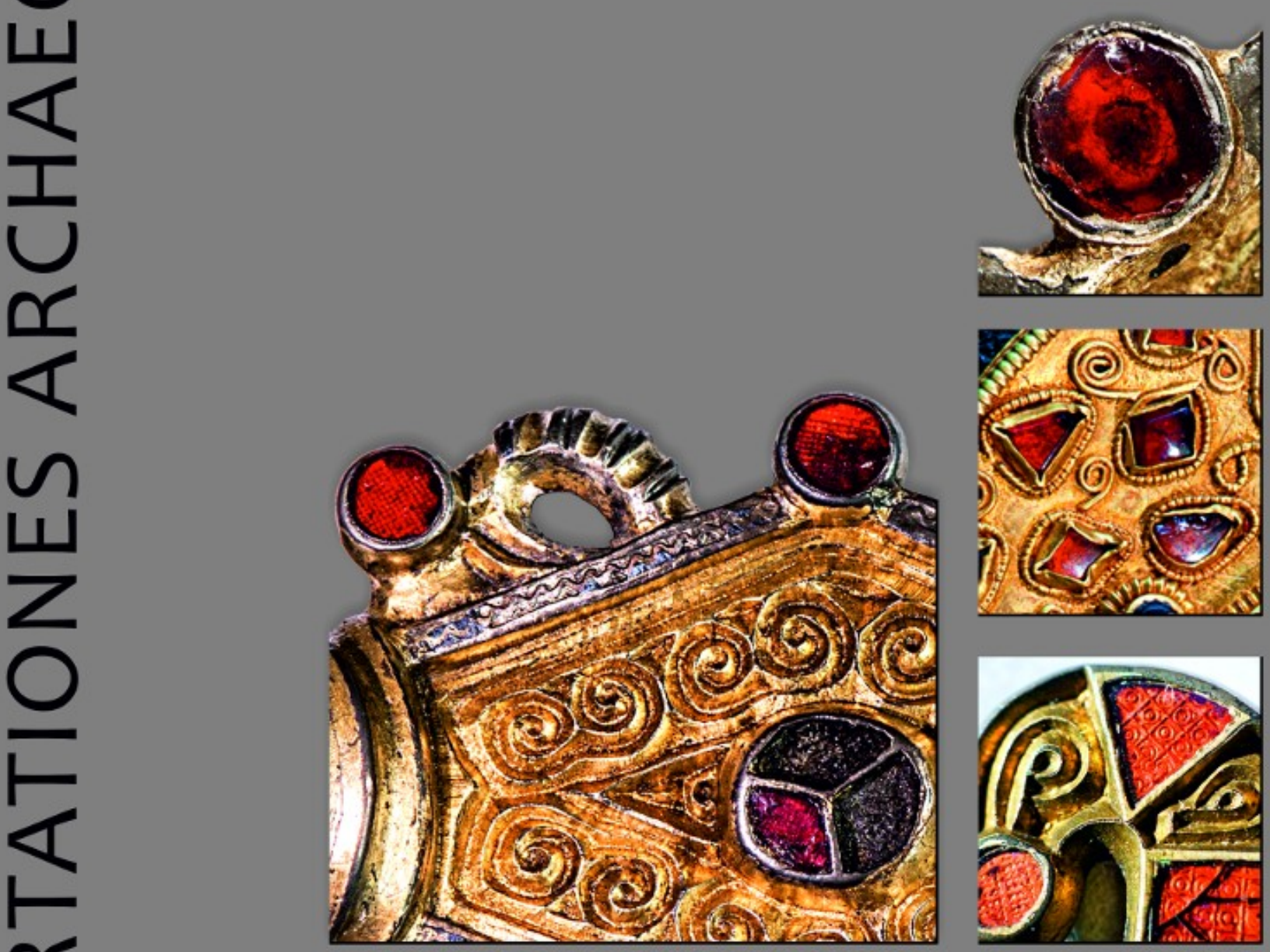

E

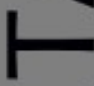

œ

山

n

ก

$\overline{0}$
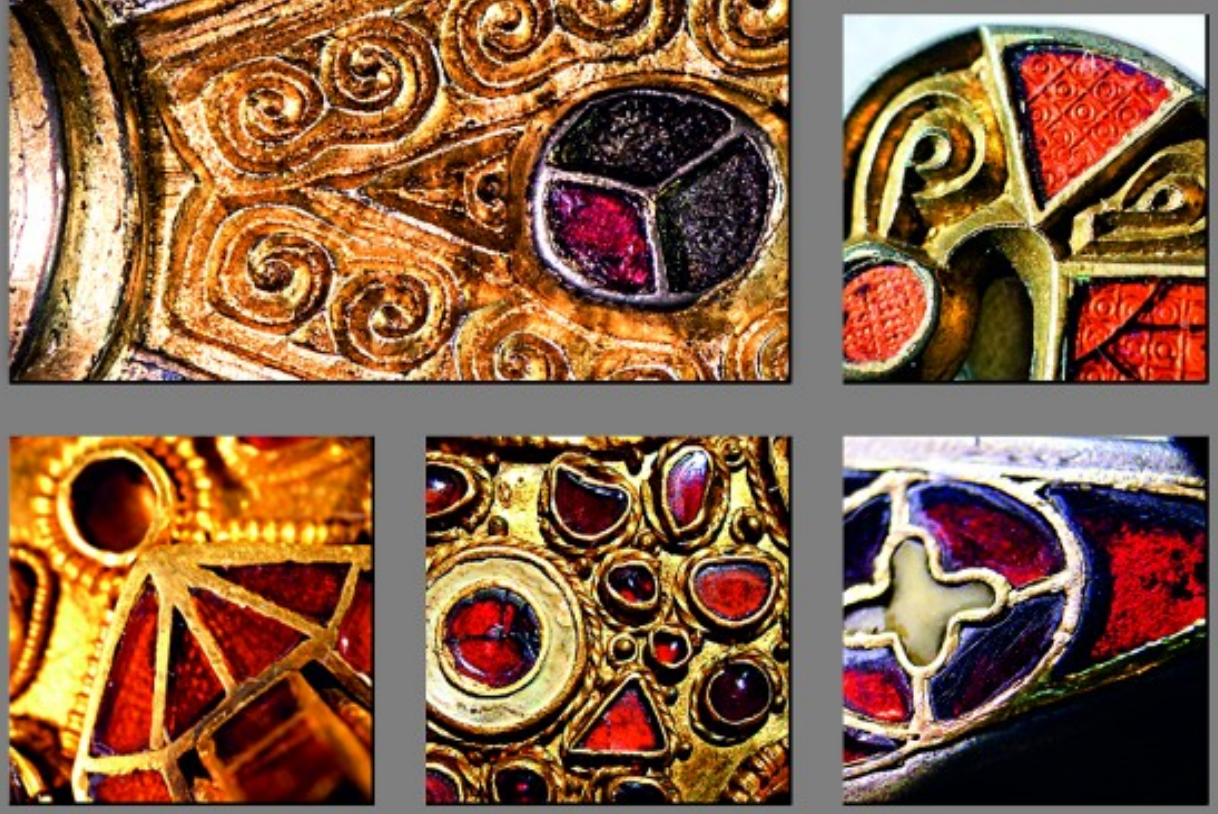

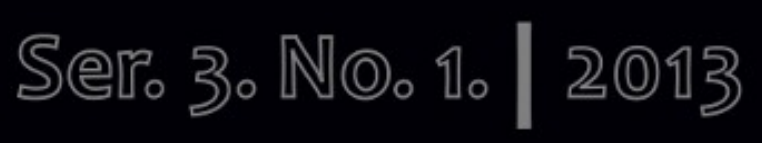




\section{Dissertationes Archaeologicae ex Instituto Archaeologico}

Universitatis de Rolando Eötvös nominatae Ser. 3. No. 1.

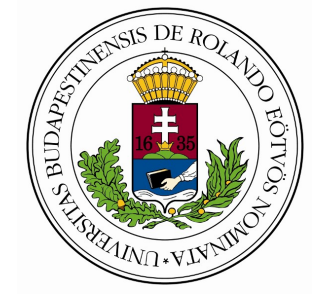

Budapest 2013 
Dissertationes Archaeologicae ex Instituto Archaeologico

Universitatis de Rolando Eötvös nominatae

Ser. 3. No. 1.

Editor-in-chief:

DÁvid BARTUS

Editorial board:

LÁSZLÓ BARTOSIEWICZ

LÁSZLÓ BORHY

ISTVÁN FELD

GÁBOR KALLA

PÁL RACZKY

Miklós SzABÓ

TIVADAR VIDA

Technical editors:

DÁvid BARTuS

GÁBOR VÁCZI

ANDRÁs BöDŐcs

Proofreading:

Zsófia KondÉ

SzILvia SzÖLlősI

Available online at http://dissarch.elte.hu

Contact: dissarch@btk.elte.hu

\section{$\underline{\text { PKP }}$ \\ PUBLIC \\ KNOWLEDGE \\ PROJECT}

(C) Eötvös Loránd University, Institute of Archaeological Sciences

Budapest 2013 


\section{Contents}

\section{Articles}

Melinda TORBÁGYI - István VIDA

The coin hoard of Abasár

Anikó BózsA

21

Roman mirrors from a private collection in the Hungarian National Museum

Lajos JuHÁsz

45

The Biesheim cameo - a reinterpretation

\section{Methods}

Péter CsIPpÁN

$A z$ állatcsont, mint információhordozó leletanyag

Kata DÉvAI

Terminológiai alapfogalmak régészeti korú üvegtárgyak elemzéséhez

Lőrinc TimáR - Zoltán Czajlik - Sándor Puszta - Balázs Holl

$3 D$ reconstructions using GPR data at the Mont Beuvray

\section{FIELD REPORTS}

Zsolt MESTER

Excavation at a new Upper Palaeolithic site of the Eger region (Northern Hungary)

László BORHY - Dávid BARTus - Emese SzÁmadó

Short report on the excavations at Brigetio (Szőny-Vásártér) in 2013

Dénes HulLÁm - Zsófia RÁcz

Report on the participation of the Eötvös Loránd University at the Wielbark Archaeological Field School in Malbork-Wielbark, Poland

Gábor VÁczi - Dávid BARTus

Short report on the excavations at the site Makó - Igási Ugar

Maxim MoRdovin

Short report on the excavations in 2013 of the Department of Hungarian Medieval and Early Modern Archaeology (Eötvös Loránd University, Budapest)

\section{THESIS ABSTRACTS}

Kitti KÖHLER

Biological reconstruction of the Late Neolithic Lengyel Culture 
Cultural connections and interactions of Eastern Transdanubia during the Urnfield period

Orsolya LÁNG

Urban problems in the civil town of Aquincum: the so-called „northern band”

Nikoletta SEY

Questions of bronze workshops in Roman Pannonia

Kata DÉvaI

Glass vessels from Late Roman times found in graves in the Hungarian part of Pannonia

Eszter HORvÁTH

Gemstone and glass inlaid fine metalwork from the Carpathian Basin:

the Hunnic and Early Merovingian Periods

Gergely SzEnTHE

Vegetal ornaments in the Late Avar decorative art

Péter LANGó

Relations between the Carpathian Basin and South East Europe during the 10th century.

The evidence of the minor objects

Ciprián HoRvÁTH

The Cemeteries and Grave Finds of Györ and Moson Counties from the Time

of the Hungarian Conquest and the Early Árpádian Age

András Sófalvi

The border- and self-defence of Szeklers from the Medieval Age till the Age of Principality.

Castles and other defence objects in the settlement history of Udvarhelyszék 


\title{
Vegetal ornaments in the Late Avar decorative art
}

Gergely SZENTHe

Hungarian National Museum

szenthe.gergely@gmail.com

\begin{abstract}
PhD thesis submitted in 2013 to the Archaeology Doctoral Programme, Doctoral School of History, Eötvös Loránd University, Budapest under the supervision of Tivadar Vida. This paper is the modified version of the abstract of my doctoral thesis. The thesis discusses the vegetal ornaments of the Late Avar period (ca. a long 8th century $A D$ ) from the perspective of the cultural history, with the aim to create a basis for social historical studies. The Late Avar period had an art of ornamental functions. According to their inner structure the four different ornamental phases of the Late Avar period may have been determined by external cultural trends mostly of the Mediterranean. As the substance of the Mediterranean 'dark age' was regionalisation, Late Avar material culture showed some autonomous features. The global cultural processes based on the social transformation of the Late Antique Mediterranean and Western-European world led to different cultural phenomena under the different social circumstances of the Avar milieu.
\end{abstract}

\section{Research background and objectives}

There was a change in the western research concerning the Avar material culture from the 1980 's, then in the Hungarian one from the beginning of the 90's as well. While earlier the Avar period was seen at most within an "eastern", steppe nomad environment, or, in point of the LateAvar period it was rather looked in the frame of an autonomous development of the Carpathian Basin, then from the 1990's the Avar culture was reckoned to be a phenomenon of the Byzantine margin. Recognizing that the culture of Byzantium, or, from the second half of the 7th century rather of the Mediterranean Basin, had great influence on people living in the surroundings of that area, came together with the centre-approach of the periphery's cultural phenomena. The tendency, the principle of which is the centre-periphery model, has had great importance so far. Its programmatic work reflects this approach even in its title. ${ }^{1}$

To some extent the result of this approach implied by the prevailing research stream is that, for today, the Avar and the Late Avar material culture were reliably settled from a cultural perspective among Mediterranean-Byzantine contexts. Therefore my thesis can be regarded as a documented fact that the ancient tradition prevails in the Late Avar ornamentation, and that the latter is a part of a Mediterranean koine.

Thus the goal of my work was not to collect more data to the Mediterranean-Byzantine roots of the Avar and Late Avar ornamental material culture, but to elaborate, as far as pos sible, the details of a picture drawn universally for today. After realizing the importance of Byzantine culture and ornamentation the archaeological research has to proceed to the regional differences of the ancient tradition, and to stylistic, qualitative aspects. By means of these aspects the examination of the ornamentation's sociological and identity formation role becomes possible behind the cultural concerns.

1 Die Awaren am Rand der byzantinischen Welt, edited by Falko Daim (DAIm 2000). 
In case of the areas located in the periphery of the Mediterranean this work is but more complicated: beside the examination of the Mediterranean trends, in case of the material cultures setting on the margin it is important to differentiate their own characteristics and the feature from the centres beyond the Basin of the Mediterranean Sea. The great cultural influence of the latter on its peripheries makes it almost impossible to distinguish between components heavily convoluted to each other; on the one hand alien of the European Mediterranean, and on the other, deriving from local communications of the Carpathian Basin cultures.

Contrary to the centre-periphery aspect, which studies the phenomena in the margin of the Mediterranean area in a view from the centre, there are other well-founded aspects as well. The archaeological culture of the Carpathian Basin reflected a process in which - during a regionalistaion of the Mediterranean culture - its regions were getting to show idiosyncrasies in their material cultures after the Byzantine dominance of the 6 th-7th centuries. Accordingly, the Late Avar era used an ornamental material culture, which was typologically unified to a previously unknown extent, and composed many characteristics specific of the Carpathian Basin.

In the examination of the Late Avar ornamentation, which can be dated to the declining period - "dark ages" or "transition period" - of the Mediterranean archaeology, it is justified to some extent applying a centre-centre model complementing the centre-periphery one. In its context we can make an attempt to do examinations from another perspective which considers each periphery as an independent unit, and compares their characteristics. Such an approach is even more promising, because the material culture of the non-Islamic Mediterranean is unknown to us apart from a few exceptions from the second half of the 7 th century until the 9th century, hence almost completely during the investigated "long 8th century" of the Late Avar period of the Carpathian Basin. ${ }^{2}$

Examinations of the trends of the Avar culture as a whole and its relations with the European-Mediterranean and - in a small part - with the steppe were centred in the analysis. During my work I had to face that although the inner and relative chronology of the Late Avar period is elaborated rather perfectly, other aspects - like social structure, production places and system, infrastructure in the late period Khaganat - were totally omitted so far. I tried to behold the latter in the perspective of my study, or rather to create a solid basis for further studies towards these questions.

\section{The classification of the ornaments}

The classification system was adapted to the special circumstances of the Late Avar material culture and to the requirements raised by the questionings of the analysis. The ornamental classification is based primarily on the mostly geometric structuring elements (like "stems" or "tendrils") of and on the symmetry in the patterns. ${ }^{3}$ On the one hand, symmetry defines at an outer level the proportions of the pattern as a whole (as there are no unending palmette patterns in the Avar decorative art, it means mostly the existence or lack of axial sym-

2 To the Mediterranean processes in universal see Morrison 2012, Horden - Purcell 2000; on the regionalization of the small finds see SCHULZE-DöRRLAMm 2009.

3 See to the point of departure the structure of Riegl's analyse in his famous work 'Stilfragen' from the year 1893 (RIEGL 1992). 
metry), on the other, symmetry manifests also by setting the position of single vegetal motifs to each other below the structural level, partly settled by the structuring elements. The secondary aspect of the classification was the differentiation between types of simple (e.g. leaves) or complex motifs (e.g. "flowers" as certain variations of palmettes permanent in the Avar milieu) applied in the pattern as structural framework (Fig. 1-2).

According to the source types and the research objectives some external aspects got in the lower levels of the classification, like style of surface modelling (flat surface with sharp verges of the more geometric style (Fig. 1,8-10) vs. smoother contoured, three-dimensional shapes of the relatively naturalistic vegetal patterns) object types and object shapes, although the latter did not modify the types and variations generated by ornamental criteria exclusively. The nearly 900 types and variations evidence the great variability of the vegetal ornaments in the long 8th century of the Late Avar material culture.

\section{Methods of the analysis}

The analysis was based on the classification of vegetal ornaments. As the author is an archaeologist, he used analogies in the formal analysis. Excluding some very reasonable cases, for the sake of the avoidance of anachronisms I collected the quoted, comparative materials beyond the Carpathian Basin according to synchrony approach from the Late Antiquity to the Early Middle Ages. Defining the frames of the time period I followed the periodisation based on Alois Riegl's definition which was the most commonly used in other works specialized in ornamental arts (From the Fall of Rome till - implicitly in my case - the end of the 9th century as it is the end of the Avar era.).

Because of the goals I set, some important research fields as the inner relations of the Carpathian Basin and some regional differences in the Avar era, or the representation of social hierarchy in the context of the Late Avar finds were neglected. But, to achieve my goals, I needed to widen the studied object into two ways, too. Through the examination of moulding techniques we got closer to the workshops and workshop structures which produced the analysed materials; ${ }^{4}$ and, secondly, for the sake of recognizing the trends and relations of the Avar ornamentation as a whole, it was necessary to complement the interpretation of the rather neutral vegetal patterns with certain elements of the figural ornamentation.

\section{The solid base - archaeological sources and their relative chronology}

The ornamented objects of the Late Avar Carpathian Basin fall under the category of the small finds without an exception. The absolute majority of them are buckles, mounts and strap ends of parade belts from the context of men's social prestige. There are other, less significant types of ornament carriers, mostly mounts of horse harnesses, carved bone plaques of quivers, some carved bone needle cases, brooches and metal vessels. Because of quantitative aspects the absolute basis of our knowledge about Late Avar decorative arts are the belt ornaments; therefore, working with the subject matter means practically the analysis of the latter material group. 

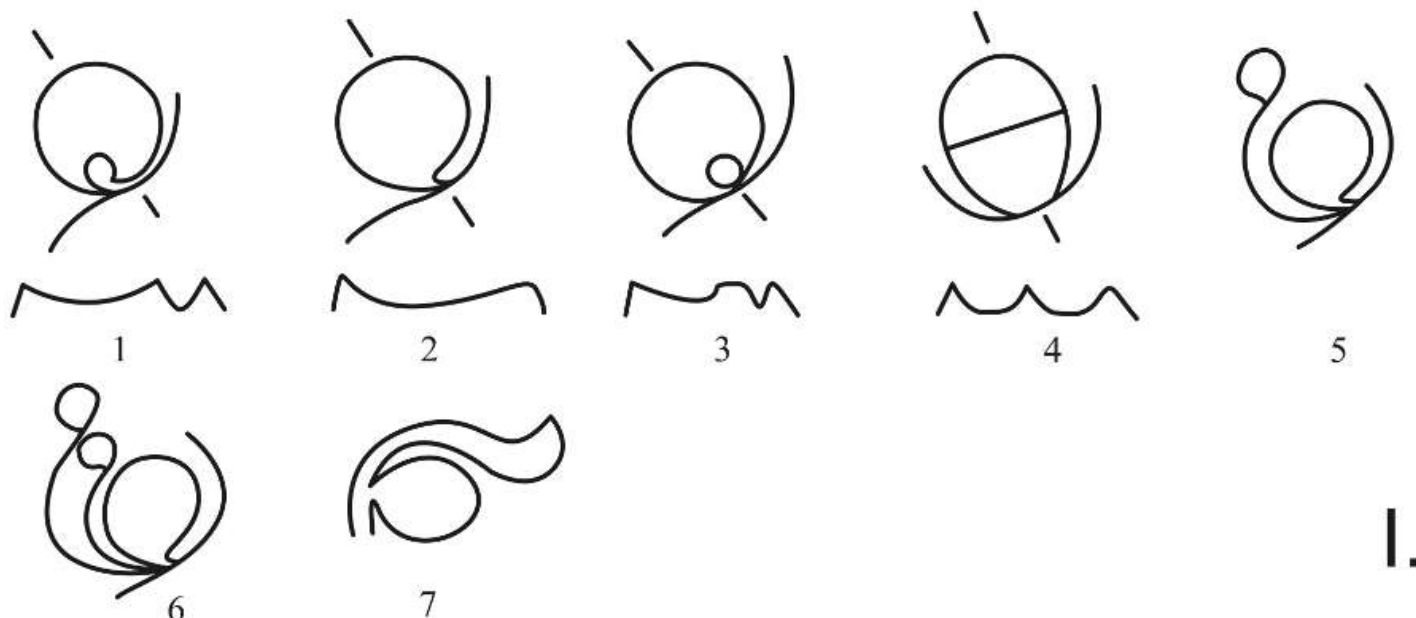

$$
7
$$
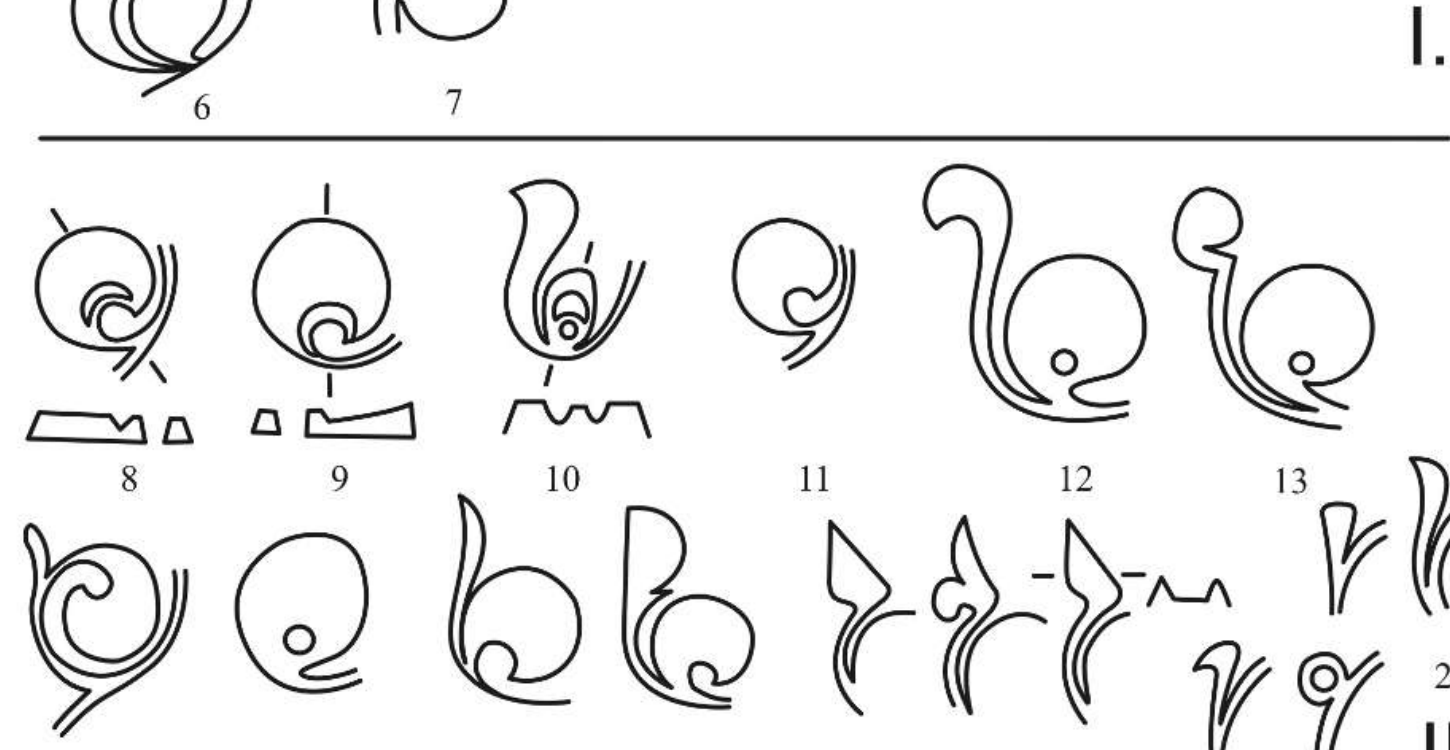

?त्वी $-\sum^{12}-1$

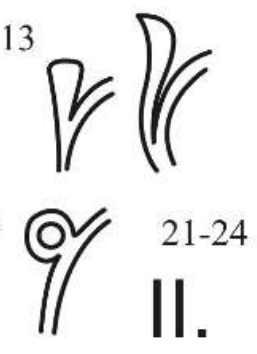

14

15

16

17

$\begin{array}{lll}18 & 19 & 20\end{array}$

. II II.

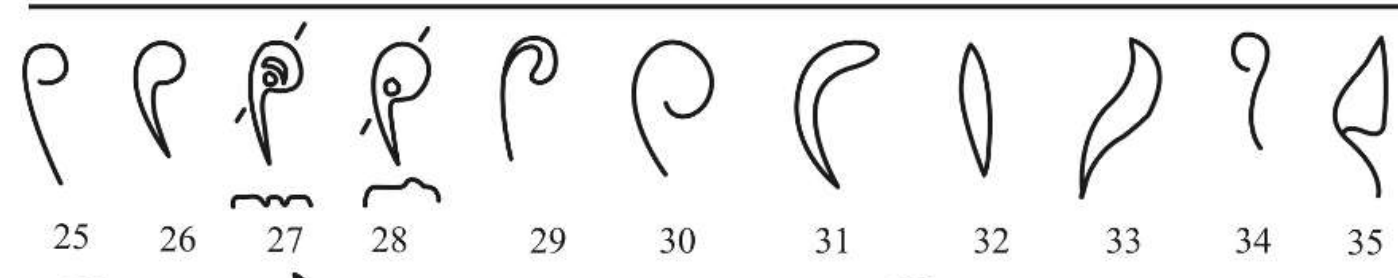

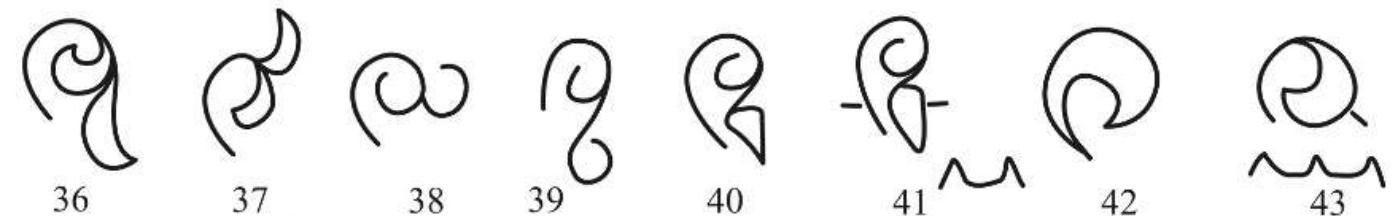

$(3) \int_{44}^{36}$

40

(

49
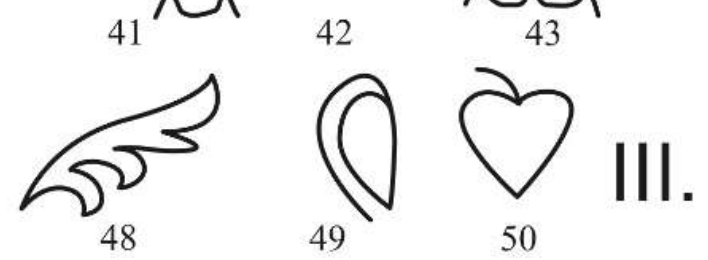

Fig. 1. Motif-types of the Late Avar era: leaves and half-palmettes. 


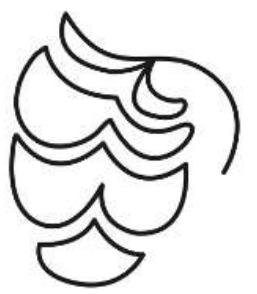

1

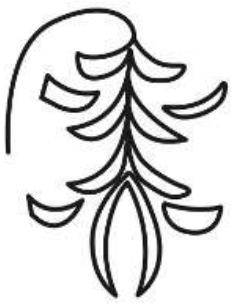

6

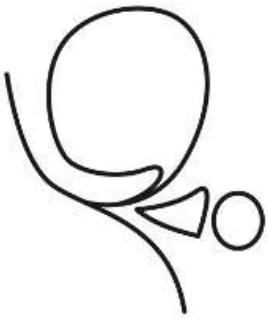

12

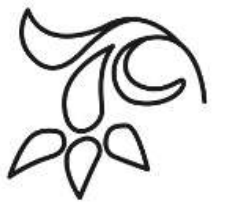

17

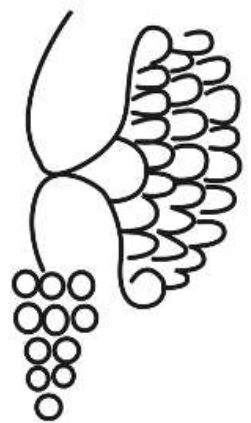

19

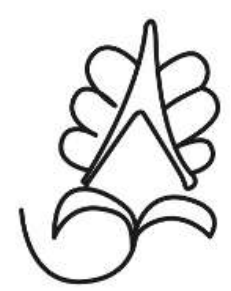

2

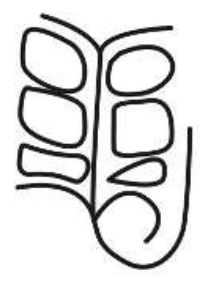

7

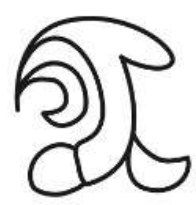

13

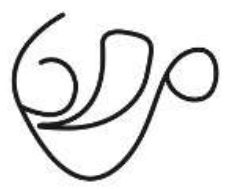

18

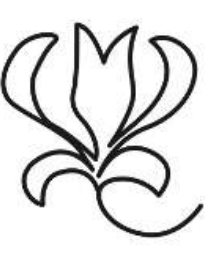

3

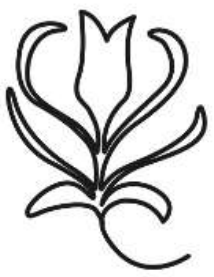

4

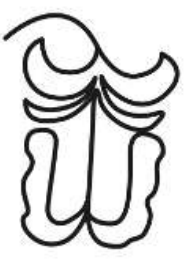

5

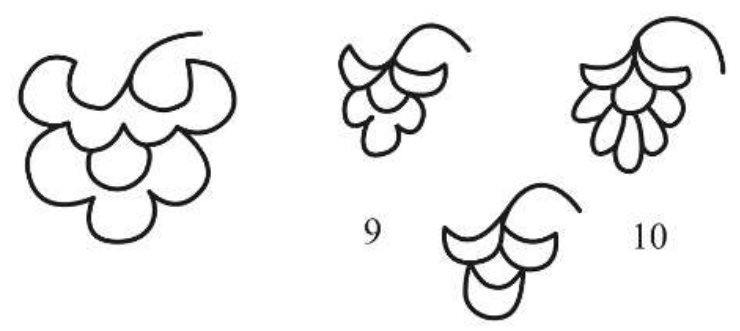

8
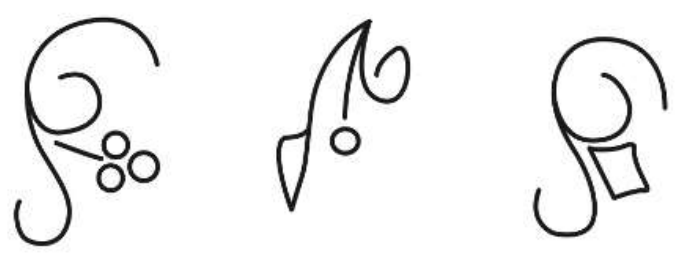

14

15

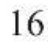

Fig. 2. Motif-types of the Late Avar era: floral palmettes regularly applied in the same forms. 
The relative chronology and a certain lack of regional diversity of the Late Avar material culture bear a special significance for the results of my work. The archaeological chronology of the Late Avar period Carpathian Basin is based on the very object group that is the main source type for my work, namely the ornaments of the parade belt sets of the men's wear. Because of their huge quantity and of the formal variety emerging from their probable prestige-function the mounts and strap ends of these belts represent an ideal subject of typology. The main works concerning Late Avar period material culture using statistical methods (seriation) were written by Jozef Zábojník and Éva Garam; ${ }^{5}$ the former undertook exclusively statistics of belt ornaments from the western periphery of the Carpathian Basin; Éva Garam published the largest Avar cemetery from East-Hungary (Tisza-region) analysed thoroughly so far. As the results of both works concerning (chronologically interpreted) relative structures are the same, and other studies verified their systems as well, ${ }^{6}$ the relative position of their material groups to each other must be relevant. For besides some exceptional sets ${ }^{7}$ all of the belt garnitures belong to the same technological niveau (one-piece cast objects) and consist of the same material (copper alloys), ${ }^{8}$ there are no hints for interpreting the relative structure of these material groups otherwise than demonstrating chronological phases. As the samples for both analyses originated from entirely different regions of the Avar settlement area, their argument is extremely firm; therefore, I could use ready relative chronological systems for the purposes of my work (Fig. 3).

\section{Results}

The analytic chapters of the dissertation do not follow the system of the classification completely. They are divided according to the stylistic and formal groups of the Late Avar ornamental art, defined rather by the surface modelling, adapted motifs and object types than by the "grammar of ornament", ${ }^{9}$ that is by the structuring elements used continuously or periodically sometimes over a considerable period of time. Thereby, it became possible to discuss each of the material groups as wholes formed by typological correspondences. Because of their above mentioned chronological succession these formal groups are the imprints in the archaeological evidence of formal trends ruling a special segment of the material culture of the Late Avar men's society.

One has to be aware of the fact that the analysed objects are just the remains of a thin layer of the material culture as a whole, although of a well-proven importance for its representative context (men's belts). Therefore, the styles and horizons described in the followings could only be meant as trends materialising in men's representation. As at some points it could be documented by other ornamented object types (metal vessels, bone carvings, brooches), the ornamentation of the belt mounts corresponded with theirs in a certain degree; but because of the rarity of such examples a systematic presentation of the decorative arts of the 8th century Carpathian Basin other and more complex than the following cannot be met at the moment.

5 ZÁBOJNÍK 1991; GARAM 1995.

6 DAim 1987; StADler 2005.

7 See SZENTHE 2013; SzEnTHE forthcoming.

8 To the problem of the material of the cast objects see DaIm 2000.

9 Grabar 1992, 38. 


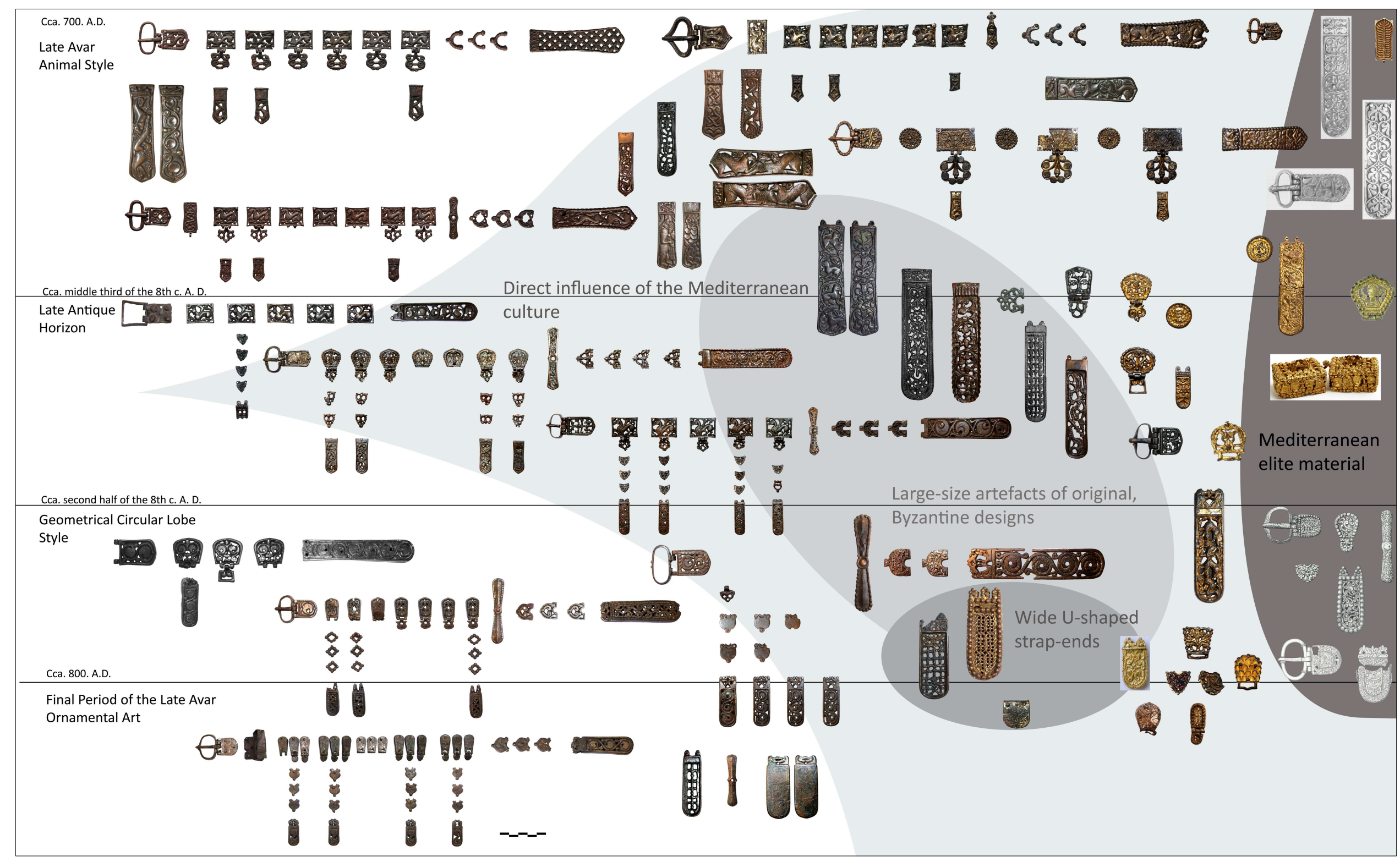

Fig. 3. Chronological and stylistic groups of the Late Avar decorative art. 
Since the stylistic phases of the Late Avar art are quite different from each other, but have good connections outside of the Carpathian Basin, I treated them as independent units in the context of their external analogies.

\section{The phases of the Late Avar decorative art}

The Late Avar art can be divided into four, formally and chronologically well separated phases (Fig. 3).

\section{Late Avar Animal Style.}

The first half of the Late Avar period (SS I-II) ${ }^{10}$ used figural ornamentation dominantly. Because of rather inconvenient contexts of research history, the definition Late Avar Animal Style is used in the dissertation instead of the traditional phrase "griffin and tendril style” of the Hungarian research terminology. ${ }^{11}$

Its main types compose an ornamentation united and locally marked in the whole Carpathian Basin, which is the first independent ornamental style of the Late Avar era. Beside the quadrupedal "griffin-like" predators, the most wide-spread vegetal designs were simple structured circular lobe ornaments (Fig. 3). Their most common design is the simple tendril filling the cycles of the scroll ornament with large, circular leafs (lobes) as dominant leaves of half-palmettes. A certain type of a simple "floral palmette" is also used (Fig. 4).

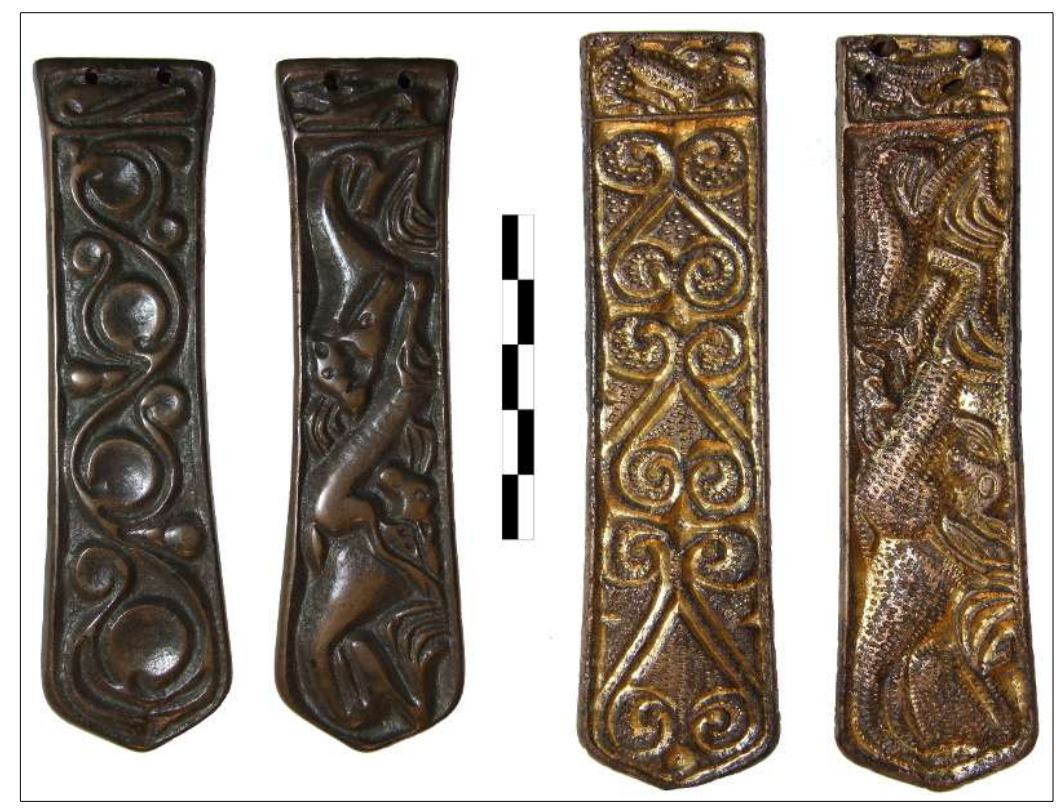

Fig. 4. Strap-ends of the Late Avar Animal Style: Unknown site (right) and Dunacsúny (Čunovo, Slovakia, left) in the Hungarian National Museum.

Rarely but all the animal figures and the foliated scroll designs of the first half of the Late Avar era can be found in the approximately contemporary Mediterranean (Byzantine, western European as well as early Muslim) ornamental art. However, the application of the pattern and motif variations in the Carpathian Basin bears a number of unique and - to the Mediterranean culture - unfamiliar elements. 


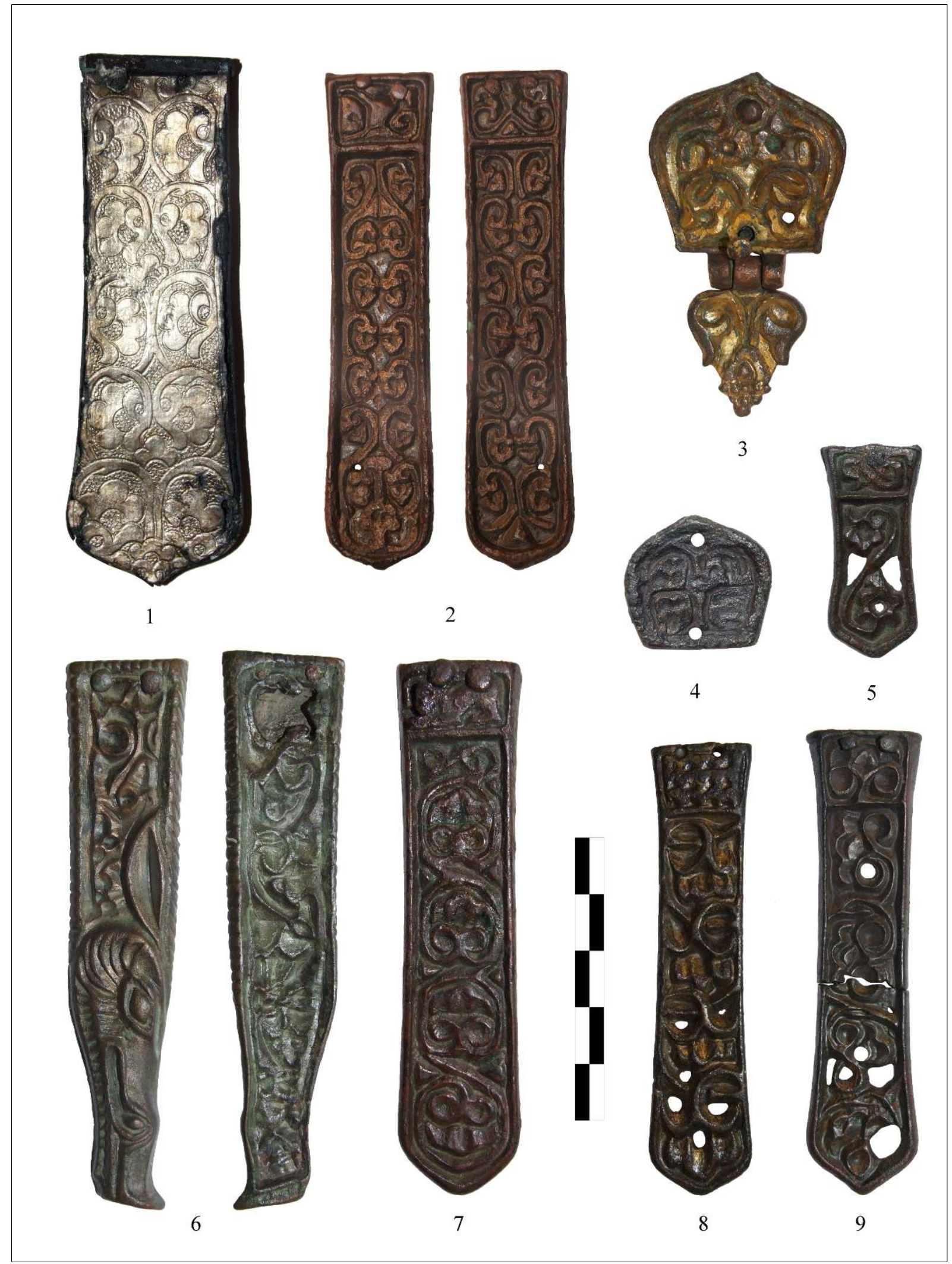

Fig. 5. Various objects with a 'floral palmette' type wide-spread in the Late Avar Animal Style (Hungarian National Museum. Photos: G. Szenthe). 


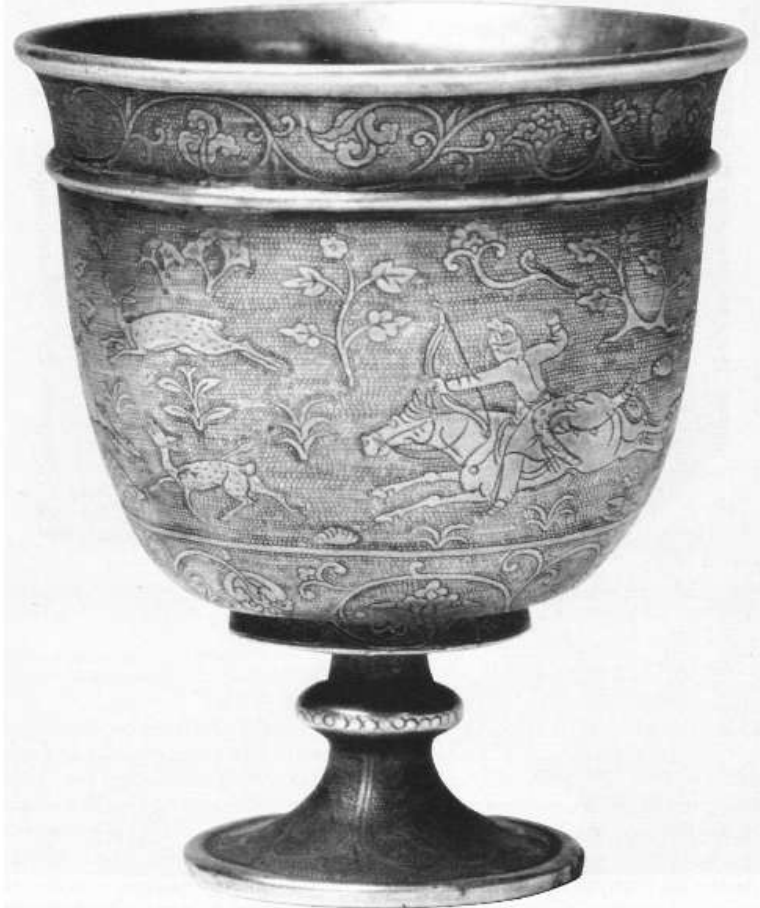

1

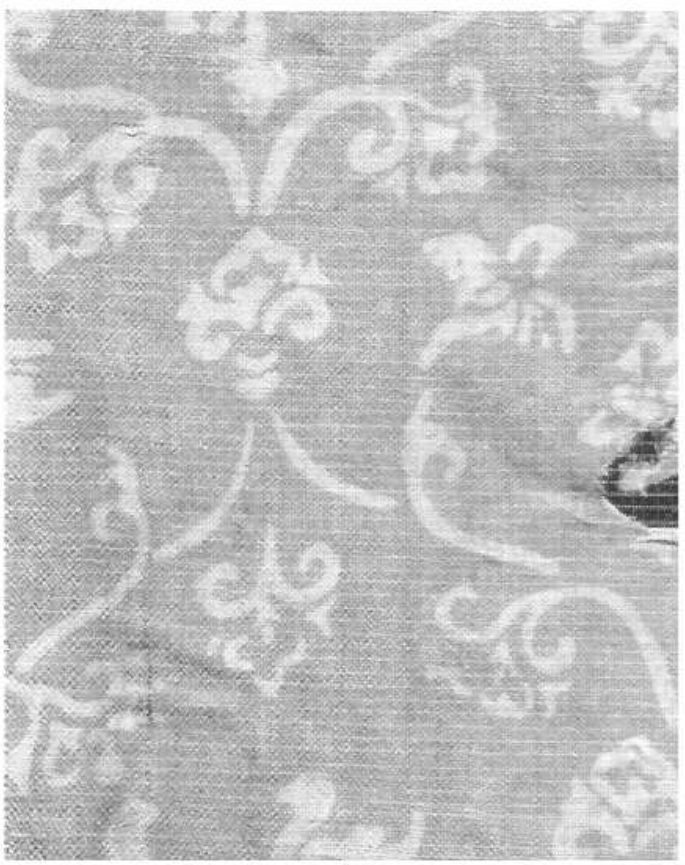

2

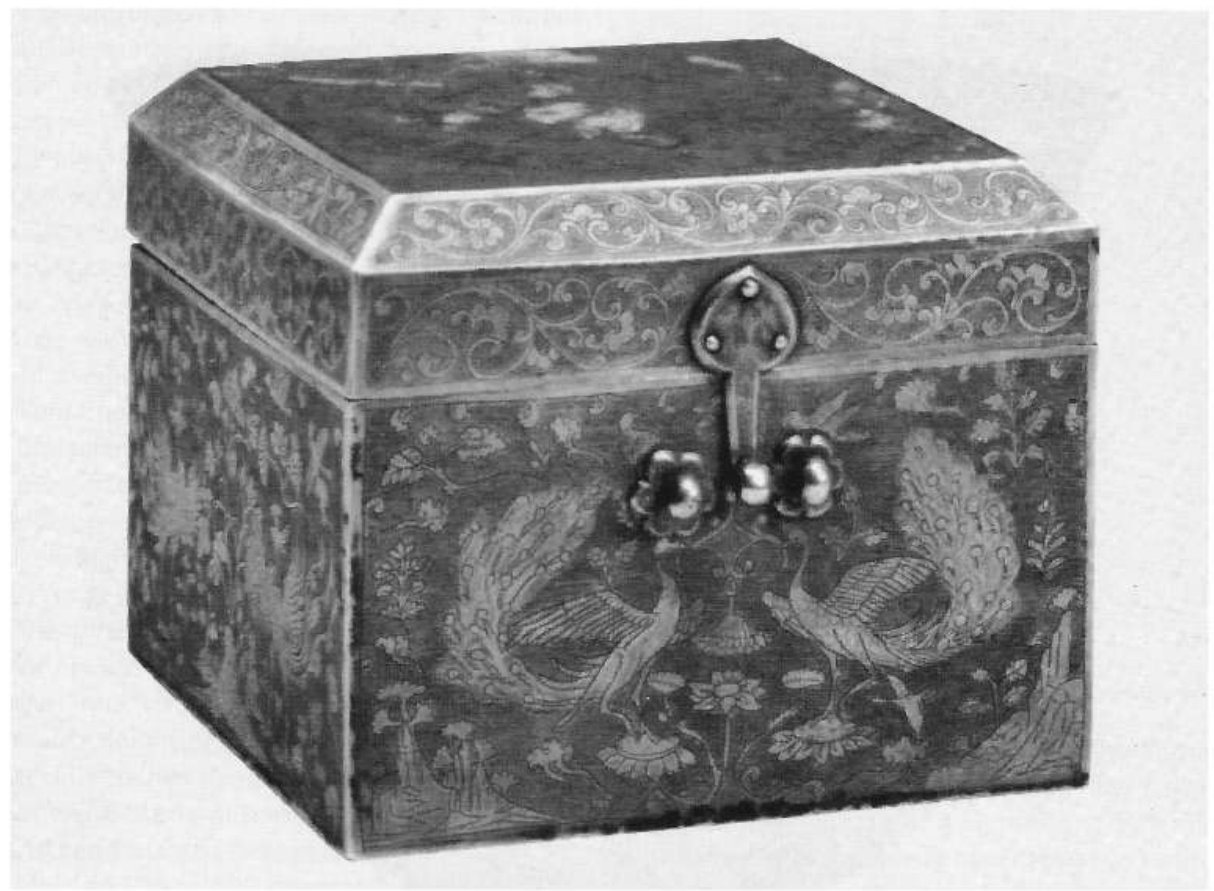

3

Fig. 6. The same floral palmette type from Inner-Asian and Chinese contexts (after DAIm 2000, Abb. 57-59). 
Contrary to the Mediterranean half-palmettes consisting of more elements with similar significance, the parallels of the circular lobe ornament's large leaves can be found more frequently in the Eastern European or Central Asian surroundings. However, the Avar variation of the "floral palmette" as a composite motif was influenced by western Central Asian - Silkroad cultures (Fig. 5), nonetheless the lobular arch of these floral palmettes as being angle-filling of palmette-designs is a well-known element of the Mediterranean (Byzantine) decorative arts (Fig. 6). As a feasible solution for this duality I suggested that a common palmette-form known in Europe but in China as well was brought with by the Avar people from CentralAsian cultural milieu to the Carpathian Basin, where it had met the more adaptable relatives of a rather angle-filling function in more complex palmettes.
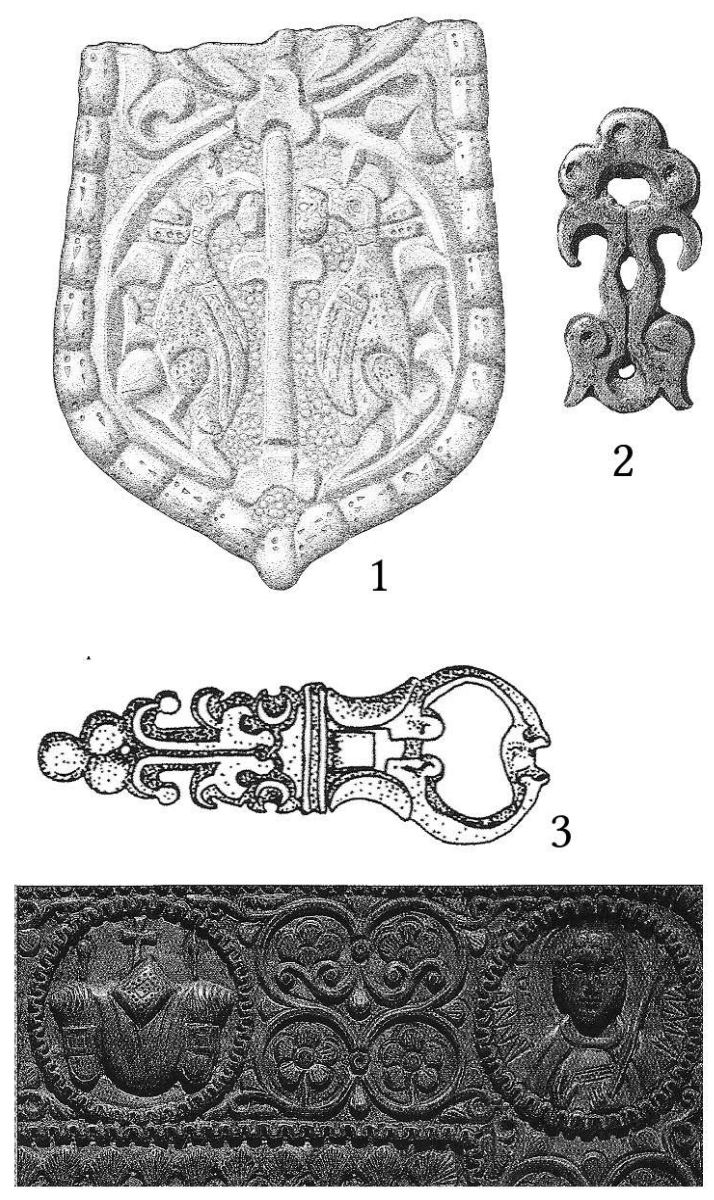

4

Fig. 7. The 'floral palmette' in the Mediterranean material culture: 1. Mikulčice (after DAIM 2000, Abb. 46b); 2. belt mount of the 'Martinovka-type' (after Ariadne Galeries 2011, Nr. 127); 3. Byzantine cast copper buckle (after Schulze-DöRrLAmM 2009, 44, Abb. 19); 4. Byzantine book-binding, 11th-12th centuries (after Temple 1991, Cat. Nr. 5).
Hypothetically, the taste producing the Late Avar animal style and some elements of the ornamental knowledge could have met in the Central Asian steppes close to the high civilizations. But for the knowledge of the Avar ornamental arts the Carpathian Basin provided the opportunity to appear. After the poverty of the nomadic material cultures, the Late Avar, varied cast-bronze materials cannot be defined without the Mediterranean and European environment. According to the examples rarely known, around the turn of the 7th and 8th centuries a trend existed in Byzantium and in its peripheries which preferred figural motifs similarly to the Late Avar Animal Style. The Late Avar Animal Style could fulfil in the environment of a Mediterranean trend randomly consistent with it, which provided its motifs as griffins or other quadrupedal predators. The motifs were adapted by the environment of the Carpathian Basin, while a number of elements (birds, vegetal elements e.g. ivy scroll) were neglected. ${ }^{12}$ Some complex iconographic schemes are good examples for the patterns in influence and the sample role of the Mediterranean culture on motifs: at the same time these scenes indicate how innovatively the Late Avar Animal Style could not only transform but also apply those pictures in its own environment which had not occurred on any identical medium types - like belt mountings - in the Mediterranean native land. ${ }^{13}$ 


\section{Late Antique Horizon}

In the second half of its application the Late Avar Animal Style (SS IIb period) ${ }^{14}$ loosened and changed. On the baseline of this process there was a wide spread in the Carpathian Basin of original Late Antique vegetal and figural motifs, patterns, decorative elements and object types which unambiguously originated from the Mediterranean (Fig. 8). The most likely chronological frame for their cumulative appearance is the middle third of the 8 th century. The new objects and forms did not just spread or appear sporadically on some areas of the Carpathian Basin, mostly on the Great Plain eastwards of the Danube where more complex and often symmetric designs of the circular lobe patterns of the Late Avar Animal Style were applied on some variants of the new-type but simple objects.

There are proves in the formal diversity and variety of the Late Antique Horizon for that the Late Avar environment was not able to adapt a trend reconstructed in its background, as well as it had been to the circular-lobe ornamentation. It could not alter but rather debase or fade some elements. Therefore, contrary to the previous times symmetrical palmettes, relatively natural and intensely diversified vegetal motifs, new objects like wide, shield-shaped belt mounts and strap-ends with attachment lugs and other decorative elements (decorative frames of the pattern-field and the object) formed such complex units which were imitated more or less unchanged by the Avar people.

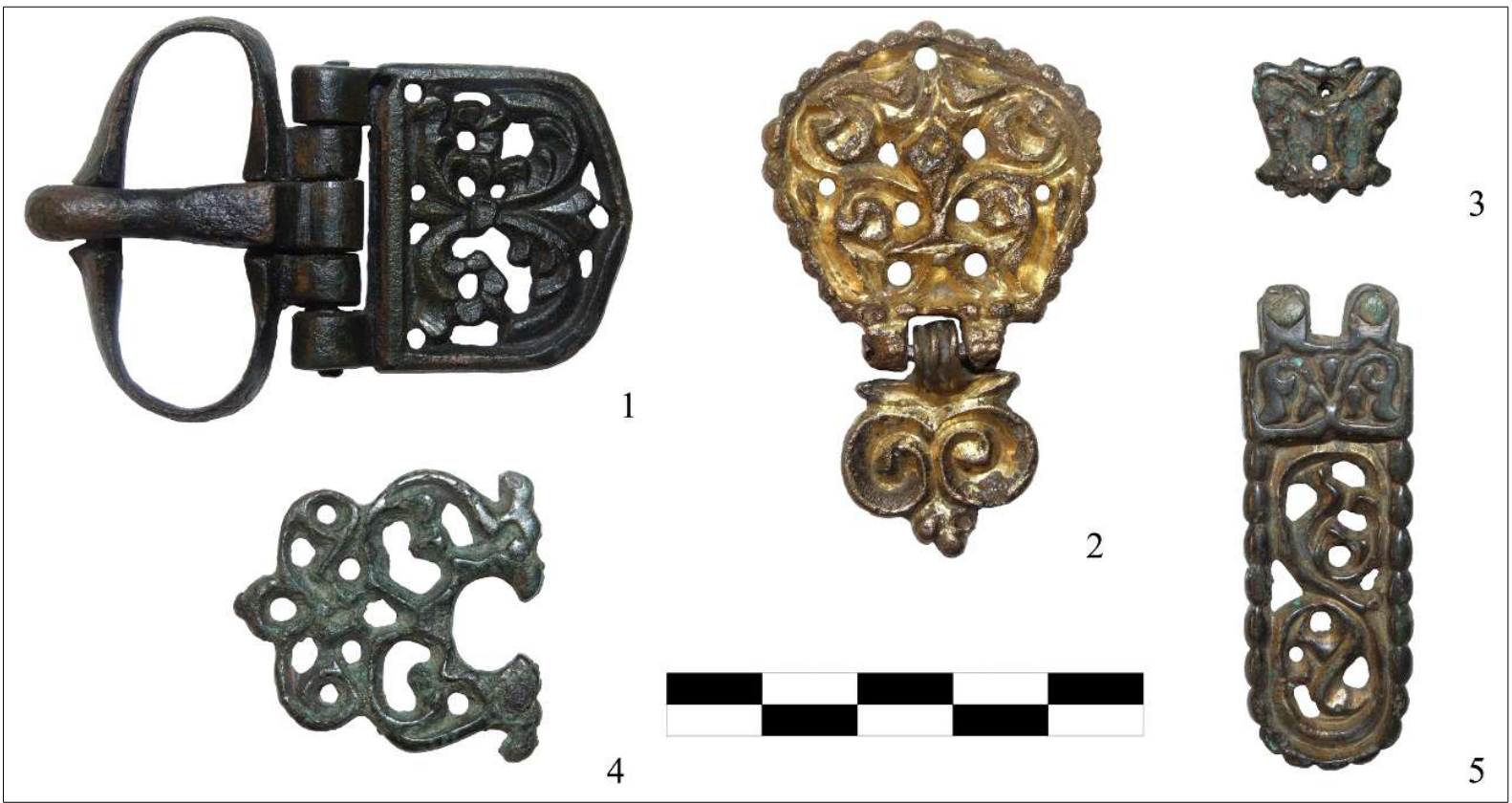

Fig. 8. Belt garniture from Kiskőrös-Városalatt (Hungarian National Museum, Photos: G. Szenthe).

\section{Geometrical Circular Lobe Style}

In the second half of the Late Avar era (SS III) circular leaved (circular-lobe) patterns became wide-spread in the Carpathian Basin once more. Absolute chronologically it is a phenomenon of the second half of the 8th century. There were applied analogous, simple designs of circular-lobe tendrils on a close variety of generalized object-types specific for the Carpathian Basin, which imply the emergence of a new decorative style (Fig. 9).

14 ZÁвојNí́ 1991, 236. 


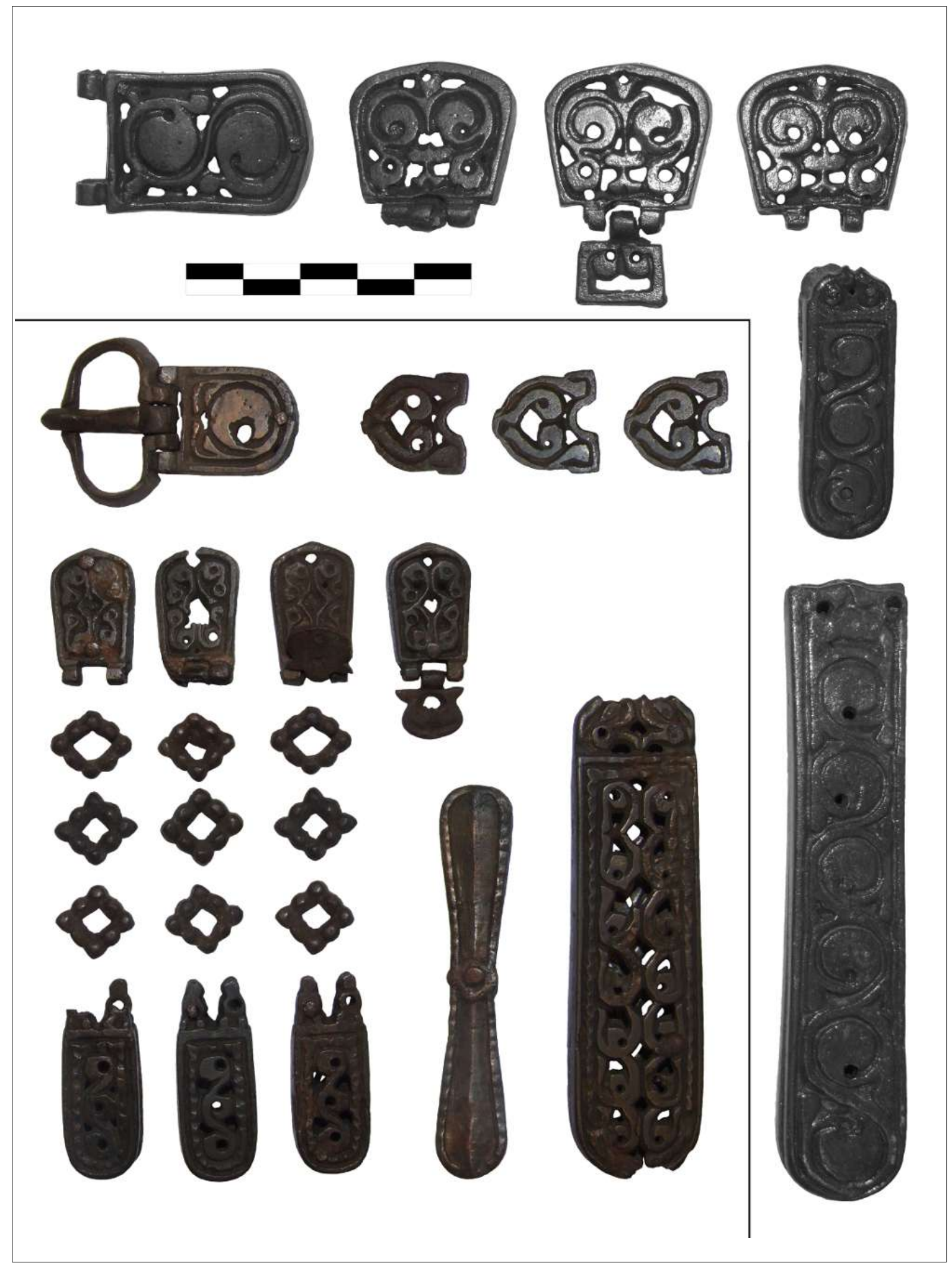

Fig. 9. Belt garnitures of the Geometrical Circular Lobe Style from an unknown site and from Alattyán, Hungary (Hungarian National Museum. Photo: G. Szenthe). 
As their patterns consist of plane-cut, schematized leaf hooks, I will refer to them as Geometrical Circular Lobe Style to distinguish them from more naturalistic circular lobes of the Late Avar Animal Style. However, it should not be left unmentioned, that not every leaf shapes a full disc, but according to type and object size there are many transitional forms to sharp, circular leaf-hooks. The ornamentation of the Geometrical Circular Lobe Style suits the preference of Late Avar Animal Style without its natural character or figural decoration.

Analogies of the geometrical circular-lobe or leaf-hook patterns can be found in the Mediterranean Basin, from Hispania to the Caucasus. A general characteristic for the latter is that they favour axial symmetric patterns in contrast with the Avar style. Regarding the cycle designs there is another difference between the two styles. Contrary to the extraordinary large circular leaves in the Avar variation, the Mediterranean patterns consist of halfpalmettes with 2-3 similar-size leaves. Their more complex character comes across against the Avar variation. Ornamentation based on the geometrical circular leaf-hooks flourished in the Mediterranean only between the 9th and 11th centuries: in this respect the patterns of the 7th and 8th centuries could be regarded rather modern.

The simplicity in the Avar variation bears that kind of a flavour which also developed the Late Avar Animal Style. Regarding the circular lobe patterns - an adaptation, which can be linked to the Avar milieu - they have been exerted an influence on the Mediterranean ornamental trend. Similarly to the Late Avar Animal Style, the Avar environment may have adapted a Mediterranean trend being seemingly close to a reconstructed Avar taste. It developed a specially Avar decorative style which was typical of the second period of the Avar ornamental art.

\section{Ornaments of the Fin-Avar Phase}

At the end of the Avar era (SS IV, most probably end of the 8th and first decades of the 9th centuries), ${ }^{15}$ the traces of the adaptive effect which previously had developed a rather own decorative art twice in the Carpathian Basin seem to largely disappear again. Like the Late Antique Horizon before the Geometrical Circular Lobe Style, the last period of the Late Avar decorative art can be also characterized as multi-coloured. As another similarity of both periods the Fin-Avar phase preferred geometrical patterns and axial-symmetric designs. The vegetal motifs adapted in the patterns are highly geometrised themselves. Compared to the vegetal patterns of the former periods, their size and significance reduced and they were cut off from natural structures, so that the vegetal motifs were degraded by their small size, dis tribution and floating to emphasise the geometry of the structure (Fig. 10).

As its most widespread ornaments, drop-shaped leaf patterns of graven and punched, flat ornaments, more sculpturesque "Stäbchenranke"-designs and the Sobor-Kiskőrös-Group formed closely related decorative horizons with certain shifts; typological nuances of the ornamentation and of various object-types. Although ornament and handicraft techniques do not constitute a whole, in this case certain shapes and patterns seem to cohere to certain techniques, e.g. leaf patterns of drop-like elements to the techniques of graving and punching. 


\section{A Mediterranean crisis symptom in particular: the Late Avar culture}

In parallel with writing the thesis, by experimental tested examinations it was managed to draw a conclusion for the system and infrastructure of casting non-ferrous metals in the Carpathian Basin. The extensive nature of the reconstructed system explains that though it was technically possible to make almost infinite numbers of the same object, we can find such examples only among a single set of mounting. Thanks to the constant re-modelling the material culture of the Late Avar era shows a very diverse picture through the typologically same objects.

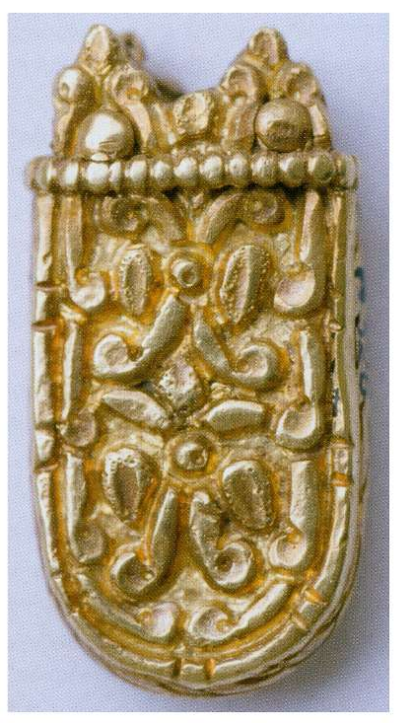

Fig. 10. Strap-ends from the end of the Avar era (after GARAM 2002, Fig. 33).

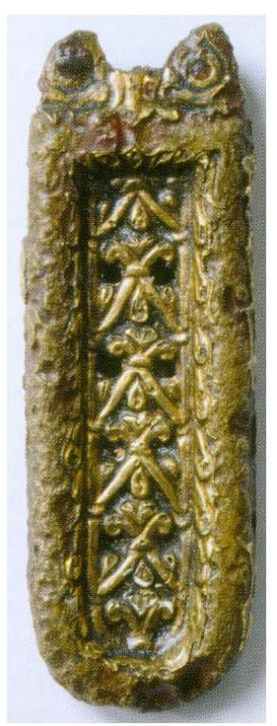

In contrast with the Byzantine design élite culture in the 7 th century, or the pieces imitating that with the same typological characteristics but using a cheaper quality material, the material culture based on the cast pieces of the 8 th century is a relapse. This phenomenon is not confined to the Carpathian Basin. That the casting technology came to the front also in the Mediterranean was a part of a degradations process, which could be accompanied by the decline of the Byzantine centre's importance. As the earlier cultural unit of the Mediterranean fell apart, moulding was applied in a wider range of the material culture. The moulding did not demand so much special technical experience compared to other, more complex goldsmith works; moreover it was an extensive phenomenon showing symptoms of a regionalisation. As this tendency reached the Mediterranean peripheries, the moulding trend spread locally fast and in a much wider range among the people living in the Northern periphery. While communication was weakening significantly, relatively independent border cultures like the Late Avar one emerged, which could have been also influenced by the centres beyond the Basin of the Mediterranean Sea.

Nevertheless, the dynamic behind the very expansive spreading of the use of the casting that was used as an exclusive device for making large parts of the material culture was most likely independent of the Mediterranean fatherlands of the process. Although in its primary milieu it was a social phenomenon that had a restricted impact on the material culture of a society although in the state of "after-complexity", ${ }^{16}$ on the Mediterranean periphery it reached societies which were originally less hierarchical and therefore more receptive to it on wider social levels (that is the most acceptable reading for the 'cultural receptivity' of barbaric people for the use of casting as a basic technology also on higher levels of social hierarchy).

\section{Conchsions: Late Avar ornamental art in the context of European cultural processes}

By its quantitative aspects the circular lobe ornamentation was in the Late Avar Animal Style and in the Geometrical Circular Lobe Style a specific feature of the Carpathian Basin, or rather its narrower central region identical with the "Avar settlement area". Although

16 LAVAN 2006, xxxv. 
nearly every aspect has its analogies in the Mediterranean, both of the ornamental groups using the circular lobe ornament as primary vegetal pattern were able to create an independent quality - a decorative art of their own.

While separated by the style of geometrised lobe ornaments in the Carpathian Basin, the two horizons of various ornamental forms are closely related to each other by a number of patterns and motifs. The substantive relationship is proved, beyond a large series of common motifs, by a preference for axial-symmetric palmette-patterns, the lily-like patterns (floralgeometric palmettes of knotted, divergent leafs on a vertical axis, mostly a spear-shaped leaf), the "Lilienzier", and by the affinity for geometrical patterns (e.g. the use of twisted ribbons for structuring the pattern).

However, there are relevant differences between the two horizons. The most significant discrepancy manifests in their relations to naturalism and floralgeometrical designs. In the earlier group the geometrical patterns and an inclination to axial-symmetry are often hidden by the relatively large, natural-like vegetal elements. In contrary, the decorative art of the last Late Avar phase designed more, smaller and mostly geometrised vegetal elements in a pattern-field of the same size. Beside the trend of the floralgeometrism the design of the pattern was more and more accentuated - instead of real connecting elements, like tendrils, the cohesion of the design was ensued by the symmetrical structure of the motifs.

Mediterranean parallels can be found beyond all four phases of decorative art separable in the Avar territory. In cases of the Late Avar Animal Style and the Geometrical Circular Lobe Style these parallels are rather premises. However, in cases of the Late Antique Horizon and the Fin-Avar phase we can detect exact analogies to our objects among artefacts prepared in Byzantium or in the Mediterranean (see the belt-mount originated from the middle third of the 8th century and found in Kiskundorozsma; see also a wider range of analogies from the turn of the 8th and 9th centuries; the most important of them are probably the finds in Hohenberg). ${ }^{17}$

Accordingly, in the phases of the Late Avar ornamental art, when an independent decorative art - simultaneously belonging to and dependent of the Mediterranean structure - came into existence in the Carpathian Basin, it had just more or less remote parallels in the Mediterranean. Quite the contrary, when the Late Avar environment seems to had been unable to adapt, or to transform the used forms to its own image, we can certainly find their close antecedents in the Mediterranean regions, mostly in the surroundings of the Avar territory.

Therefore cultural trends alien in the Avar milieu - which can be reconstructed reflecting in the Late Avar decorative art - were not the own innovations of the Late Avar Carpathian Basin. Their native land could be found in any region of the Mediterranean that is related to the Carpathian Basin. The Avar milieu adapted or adopted the formal sets transmitted through communication according to its own sense of taste; in cases of trends of simpler leaf-ornaments it meant a total adaptation creating own styles; if more complex ornamentsets were used, they could be only adopted, and copied rather unaltered, and more frequently debased. Accordingly, the geometrising process that could be more and more concretely detected in the successive phases of vegetal ornamentation in the 8th century responds very likely to Mediterranean trends, though it may also have some regional characteristics.

17 On both finds and their surroundings in the material culture, see DAIM 2010. 
After a relatively naturalistic Late Avar Animal Style, the Late Antique Horizon combined a preference for geometric patterns with naturalistic view of vegetal motifs; the severe leafpatterns of the Geometrical Circular Lobe Style were followed by an emphasised geometry and symmetry in the Fin-Avar phase on every level of ornamental structures.

There are traces of several independent ornamental traditions existing approximately at the same time through the 7th and 8th centuries in the Mediterranean material culture, reflected by the small objects of personal use. It was ambiguous in view of the dating difficulties and the great geographical distances among the sporadically survived records, whether the analogous pieces belonged to the same time-bound trends ("modes") or they did not. Nevertheless, the trends reconstructed by the Avar appearance of these common ornamental streams seem to be well-embedded into the processes of the Mediterranean. For this reason the Late Avar decorative art, the records of which are multitudinous and chronologically well-divided may have a significant contribution to the cognition of the "dark-ages" of the Mediterranean in the Late Antiquity and Early Middle Ages. The Late Avar decorative art was not a separated phenomenon intelligible in the environment of the Carpathian Basin, but a loop in the chain connecting the Antiquity and the early medieval Europe.

\section{References}

Ariadne Galleries 2011: Treasures of the dark Ages in Europe. Ariadne Galeries, New York.

Bierbrauer, V. 1997: Tierornamentik. In: Lexikon des Mittelalters VIII. München, 783-784.

BíRó, Cs. - Szenthe, G. 2011: Öntéstechnikai vizsgálatok késő avar kori bronztárgyakon. Sorozatok modellezése és sokszorosítása. Investigations of casting techniques of late bronze artefacts from the late avar period. Modelling and production of serial pieces. In: Tóth, E. - VIDA, I. (eds.), Corolla Museologica Tibor Kovács dedicata. Libelli Archaeologici Ser. Nov. No. IV. Magyar Nemzeti Múzeum, Budapest, 155-174.

DAIM, F. 1987: Das awarische Gräberfeld von Leobersdorf, Niederösterreich. Studien zur Archäologie der Awaren 3. Wien.

DAIm, F. 2000: „Byzantinische” Gürtelgarnituren des 8. Jahrhunderts. In: DAIm, F. (Hrsg.), Die Awaren am Rand der byzantinischen Welt. Monographien zur Frühgeschichte und Mittelalterarchäologie 7. Innsbruck, 77-204.

DAim, F. 2001: Byzantine Belts and Avar Birds. Diplomacy, Trade and Cultural Transfer in the Eight Century. In: Pohl, W. - Wood, I. - Reimitz, H. (eds.), The Transformations of Frontiers. From Late Antiquity to the Carolingians. The Transformation of the Roman World Vol. 10. LeidenBoston-Köln 2001, 143-188.

DAIM, F. 2010: Byzantine Belt Ornaments of the 7th and 8th Centuries in Avar Contects. In: ENtwistle, Ch. - Adams, N. (eds.), 'Intelligible Beauty'. Recent Research on Byzantine Jewellery. London, 61-71.

Garam, É. 1995: Das awarenzeitliche Gräberfeld von Tiszafüred. Cemeteries of the Avar Period (567-829) in Hungary Vol. 3. Budapest.

Garam, É. 2002: The connection of the Avar period princely and common gravegoods with the Nagyszentmiklós treasure. In: Garam, É (ed.), The Gold of the Avars. The Nagyszentmiklós Treasure. Budapest, 81-111.

Grabar, O. 1992: The Mediation of Ornament. Bollingen Series XXXV. Washington. 
Horden, P. - Purcell, N. 2000: The Corrupting Sea. A Study of Mediterranean History. Oxford.

LAVAN, L. 2006: Explaining Technological Change: Innovation, Stagnation, Recession and Replacement. In: Lavan, L. - Zanini, E. - Sarantis, A. (eds.), Technology in Transition A.D. 300-650. Late Antique Archaeology Vol. 4, Leiden-Boston, xv-xl.

Morrison, C. 2012: (ed.) Trade and Markets in Byzanzium. Washington.

RIEGL, A. 1992: Problems of Style. Foundations for a History of Ornament. Princeton - New Jersey.

Schulze-Dörlamm, M. 2009: Byzantinische Gürtelschnallen und Gürtelbeschläge im Römisch-Germanischen Zentralmuseum. Teil 2. Die Schnallen mit Scharnierbeschläg und die Schnallen mit angegossenenm Riemendurchzug des 7. bis 10. Jahrhunderts. Kataloge Vor- und Frühgeschichtlicher Altertümer Bd. 30,1. Mainz.

Stadler, P. 2005: Quantitative Studien zur Archäologie der Awaren I. Österreichische Akademie der Wissenschaften Phil.-hist. Klasse, Mitteilungen der Prähistorischen Kommission Bd. 60. Wien.

Szenthe, G. 2012: Meister und ihre Kunden. Herstellung und Verbreitung gegossener Bronzegegenstände im spätawarenzeitlichen Karpatenbecken. Archaeologiai Értesítő 137, 57-75.

Szenthe, G. 2013: Antique Meaning - Avar Significance. Complex Iconographic Schemes on Early Medieval Small Objects. Acta Archaeologica Academiae Scientiarum Hungariae 64, 139-172.

Szenthe, G., forthcoming: Connections between the Mediterranean and the Carpathian Basin in the 8th century AD. On the hinged strap-ends of the Late Avar Period. Acta Archaeologica Carpathica, forthcoming.

Temple, R. 1991: (ed.) Early Christian and Byzantine Art. The Temple Gallery, London 1990.

ZÁвојNíк, J. 1991: Seriation von Gürtelbeschlaggarnituren aus dem Gebiet der Slowakei und Österreichs (Beitrag zur Chronologie der Zeit des Awarischen Kaganats). In: ČilinskÁ, Z. (ed.), K problematike osídlenia stredodunajskej oblasti vo včasnom stredoveku. Nitra, 219-321. 